\title{
Aberrant expression of the microtubule- associated protein tau is an independent prognostic feature in prostate cancer
}

\author{
Cornelia Schroeder ${ }^{2 \dagger}$, Jan Grell ${ }^{1 \dagger}$, Claudia Hube-Magg ${ }^{1}$, Martina Kluth $^{1}$, Dagmar Lang ${ }^{1}$, Ronald Simon ${ }^{1 *}$ (D), \\ Doris Höflmayer', Sarah Minner', Eike Burandt', Till S. Clauditz', Franziska Büscheck', Frank Jacobsen', \\ Hartwig Huland ${ }^{3}$, Markus Graefen ${ }^{3}$, Thorsten Schlomm ${ }^{4}$, Guido Sauter ${ }^{1}$ and Stefan Steurer ${ }^{1}$
}

\begin{abstract}
Background: Microtubule-associated protein Tau (MAPT) overexpression has been linked to poor prognosis and decreased response to taxane-based therapies in several cancer types, but its relevance in prostate cancer is unknown.

Methods: In this study, MAPT expression was analyzed by immunohistochemistry on a tissue microarray containing 17,747 prostate cancers.

Results: MAPT was absent in normal prostate epithelial cells but detectable in 1004 (8.2\%) of 12,313 interpretable cancers. Its expression was associated with advanced tumor stage, high Gleason grade, positive lymph nodes, and early biochemical recurrence ( $p<0.0001$ each). For example, MAPT was found in $3.6 \%$ of 2072 Gleason $\leq 3+3$ cancers but in $14.4 \%$ of 704 Gleason $\geq 4+4$ cancers. High-level MAPT staining was also linked to TMPRSS2:ERG fusions $(p<0.0001)$. MAPT staining was seen in 15.2 and 16\% of cancers with TMPRSS2:ERG fusion detected by immunohistochemistry and fluorescence in-situ hybridization, but in only 3.5 and 3.9\% of cancers without ERG staining or ERG rearrangements. Moreover, an association was found between MAPT expression and PTEN deletions, with 19\% MAPT positivity in 948 PTEN deleted cancers but only 7\% MAPT positivity in 3895 tumors with normal PTEN copy numbers $(p<0.0001)$. Multivariate analysis revealed that the prognostic value of MAPT was independent from established parameters. Conventional large section analyses showed intratumoral MAPT heterogeneity in all three analyzed cancers.
\end{abstract}

Conclusions: The results of our study identify MAPT, as a moderate prognostic marker in prostate cancer, whose clinical impact, however, may be limited due to the rarity and heterogeneity of its expression.

Keywords: MAPT, Tau, ERG, PTEN, Deletion, Prostate cancer

\section{Background}

In men with Western lifestyle the most prevalent cancer is prostate cancer [1]. Although most cancers show an indolent course, the disease still represents the third most common cause of cancer related death in men. Therefore a specific and sensitive prediction of aggressive forms is warranted to improve decision-making $[2,3]$. At

\footnotetext{
* Correspondence: r.simon@uke.de

${ }^{\dagger}$ Cornelia Schroeder and Jan Grell contributed equally to this work. ${ }^{1}$ Institute of Pathology, University Medical Center Hamburg-Eppendorf, Martinistrasse 52, D-20246 Hamburg, Germany

Full list of author information is available at the end of the article
}

present Gleason grade and tumor extent on biopsies, preoperative prostate-specific antigen (PSA), and clinical stage are established pretreatment prognostic parameters. These parameters are statistically powerful but not sufficiently reliable for optimal individual outcome prediction. For example the Gleason grade suffers from substantial interobserver variation [4]. Therefore the identification of new clinically applicable molecular markers may enable a more reliable prediction of prostate cancer aggressiveness in the future.

MAPT facilitates tubulin assembly and microtubule stabilization [5]. MAPT is mainly expressed in neuronal axons and glial cell cytoplasm, but is also present in 
various non-neuronal cells including lymphocytes, epithelial and glandular cells [5-8]. Aberrant expression of MAPT has been reported for many cancer types such as gastric, breast, and colorectal cancer [9-12], and has been linked to adverse tumor features and poor prognosis in some of them [12]. Little is known about the role of MAPT in prostate cancer. Only a few studies demonstrated MAPT expression in prostate cancer cell lines and in clinical samples but did not attempt to link MAPT expression to clinical features of the disease [13-15]. However, MAPT might be of interest in prostate cancer since overexpression has been found to represent a prognostic marker in several cancers $[12,16,17]$. MAPT overexpression has also been linked to resistance to taxane-based therapies in various other cancer types [10-12, 18]. To date, taxanes are the most important cytotoxic agents for advanced and hormone-refractory prostate cancer [19-21].

Here, we employed a large - more than 17,000 prostate cancers - and highly annotated tissue microarray (TMA) to elucidate the role of MAPT expression in this disease.

\section{Methods}

\section{Patients}

The 17,747 patients had radical prostatectomy between 1992 and 2014 at the University Medical Center Hamburg-Eppendorf (Department of Urology and the Martini Clinics). Follow-up was available for 14,464 patients with a median follow-up of 48 months (range: 1 to 275 months; Table S1). PSA recurrence was defined as a postoperative PSA of $0.2 \mathrm{ng} / \mathrm{ml}$ and increasing in subsequent measurements. Histological analysis was done by a standard method [22]. Quantitative Gleason grading was performed using the percentage of Gleason 4 and tertiary Gleason 5 patterns as described before [23]. The TMA spot size was $0.6 \mathrm{~mm}$ and each TMA had internal controls with normal prostate tissue [24, 25]. The highly annotated TMA contained data on ERG expression [26], $E R G$ break apart fluorescence in situ hybridization (FISH) [27] and deletion status of 5q21 (CHD1) [28], 6q15 (MAP3K7) [29], 10q23 (PTEN) [30]) and 3p13 (FOXP1) [31]) cancers.

\section{Immunohistochemistry (IHC)}

Freshly cut TMA sections were stained the same day and in one experiment. Slides were deparaffinized and exposed to heat-induced antigen retrieval for $5 \mathrm{~min}$ in an autoclave at $121^{\circ} \mathrm{C}$ in pH 7.8 Tris-EDTA-citrate buffer. Primary antibody specific for MAPT (mouse monoclonal antibody, clone 2B2.100, Biomol GmbH, Germany; cat\#T1029; dilution 1:450) was applied at $37^{\circ} \mathrm{C}$ for $60 \mathrm{~min}$. Bound antibody was visualized with the EnVision Kit (Dako, Glostrup, Denmark) according to the manufacturer's directions. MAPT staining was found in the cytoplasm of cells. In MAPT positive cancers, staining was mostly seen in all

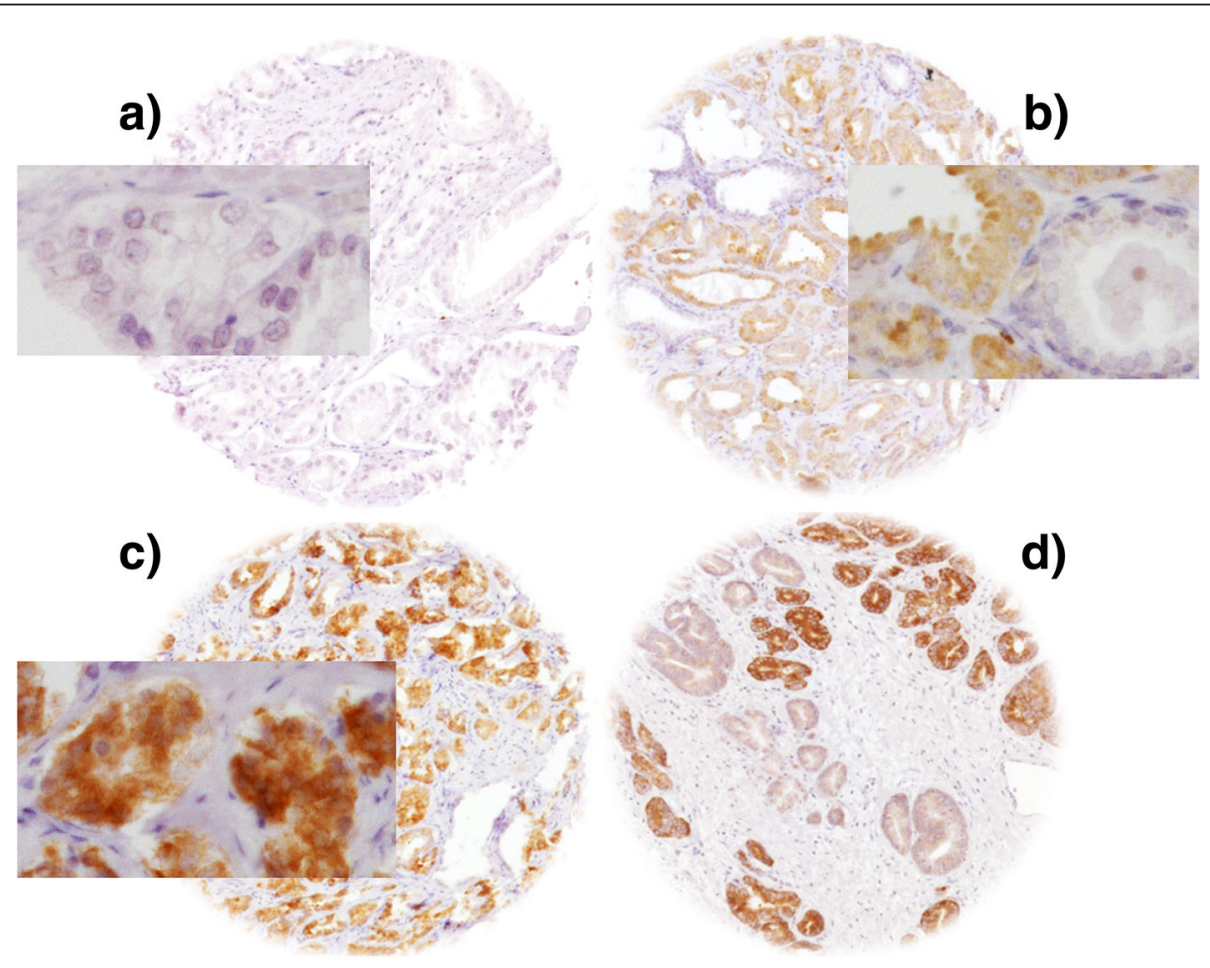

Fig. 1 Representative images of (a) negative, (b) low, (c) high and (d) heterogeneous microtubule-associated protein Tau (MAPT) staining in prostate cancer at 100x and 400x (inset) magnification; original spot size was $600 \mu \mathrm{m}$ 
(100\%) tumor cells. Accordingly, the average staining intensity in prostate cancer cells was recorded in three categories as negative (no detectable staining), low and high staining (Fig. 1).

\section{Statistical analysis}

Contingency tables and the chi-square test were computed to study association between MAPT expression and clinico-pathological variables. Kaplan-Meier analysis and the log-rank test were employed with PSA recurrence as the endpoint. Cox proportional hazards were calculated in a uni- and a multivariate model to test for independence and significance of the variables. JMP 12 (SAS Institute Inc., NC, USA) was used.

\section{Results}

A total of $12,313(69 \%)$ of tumor samples were interpretable. Reason for non-informative cases (5434 spots; 31\%) included lack of tissue samples or absence of unequivocal cancer tissue in the TMA spot. Normal prostate tissues showed no staining. In tumors, MAPT staining was seen in $8.2 \%(1004 / 12,313)$ samples and was considered low in $7.1 \%$ and high in $1.1 \%$ of cancers. Typical pictures of MAPT immunostaining are given in Fig. 1. Because heterogeneous findings were occasionally seen in TMA spots (Fig. 1d), three cancers with high MAPT expression were selected for analysis of intratumoral heterogeneity. In these cases, additional IHC analysis was done on conventional large sections of all available tumor-containing tissue blocks. Ten slides per cancer were analyzed. All cancers showed distinct areas with and without MAPT staining.

\section{Association with TMPRSS2:ERG fusion status and ERG protein expression}

MAPT staining and TMPRSS2:ERG fusion status by FISH were available from 5028 and by IHC from 7500 cases. In 96\% (4644/4849) of the cases ERG FISH and IHC results were concordant. MAPT staining was linked to TMPRSS2:ERG rearrangement and ERG positivity (Additional file 1: Figure S1).

\section{Association with tumor phenotype and PSA recurrence}

MAPT expression levels were significantly associated with advanced tumor stage, high Gleason grade, positive nodal stage, and positive resection margin $(p \leq 0.0011$ each, Table 1). These associations held also true in the subsets of ERG negative and ERG positive cancers, although not all $p$ values remained significant probably due to the overall small numbers of MAPT positive cancers (Additional file 1: Table S2 and S3). High MAPT expression levels were also associated with a higher risk for biochemical recurrence in all cancers and in the subsets of ERG positive and ERG negative cancers $(p<0.0001$ each,
Table 1 Association between microtubule-associated protein Tau (MAPT) staining and prostate cancer phenotype

\begin{tabular}{|c|c|c|c|c|c|}
\hline \multirow[b]{2}{*}{ Parameter } & \multirow[b]{2}{*}{$\mathrm{N}$} & \multicolumn{3}{|l|}{ MAPT (\%) } & \multirow[b]{2}{*}{ P } \\
\hline & & Negative & Low & High & \\
\hline All cancers & 12,313 & 91.8 & 7.1 & 1.1 & \\
\hline \multicolumn{6}{|l|}{ Tumor stage } \\
\hline pT2 & 7764 & 94.2 & 5.2 & 0.6 & \multirow[t]{3}{*}{$<0.0001$} \\
\hline рT3a & 2809 & 88.9 & 9.6 & 1.5 & \\
\hline pT3b-pT4 & 1688 & 85.7 & 11.7 & 2.6 & \\
\hline \multicolumn{6}{|l|}{ Gleason grade } \\
\hline$\leq 3+3$ & 2072 & 96.4 & 3.3 & 0.3 & \multirow[t]{6}{*}{$<0.0001$} \\
\hline $3+4$ & 6702 & 92.6 & 6.7 & 0.8 & \\
\hline $3+4$ Tertiary 5 & 614 & 91.0 & 8.1 & 0.8 & \\
\hline $4+3$ & 1257 & 88.5 & 9.7 & 1.8 & \\
\hline $4+3$ Tertiary 5 & 925 & 86.3 & 10.9 & 2.8 & \\
\hline$\geq 4+4$ & 704 & 85.5 & 11.6 & 2.8 & \\
\hline \multicolumn{6}{|c|}{ Lymph node metastasis } \\
\hline No & 7604 & 91.3 & 7.5 & 1.2 & \multirow[t]{2}{*}{$<0.0001$} \\
\hline $\mathrm{N}+$ & 943 & 85.9 & 11.7 & 2.4 & \\
\hline \multicolumn{6}{|c|}{ Preoperative PSA level (ng/ml) } \\
\hline$<4$ & 1418 & 89.6 & 8.9 & 1.6 & \multirow[t]{4}{*}{0.0506} \\
\hline $4-10$ & 7278 & 92.3 & 6.7 & 1.0 & \\
\hline $10-20$ & 2629 & 91.8 & 7.2 & 1.0 & \\
\hline$>20$ & 918 & 91.8 & 7.3 & 0.9 & \\
\hline \multicolumn{6}{|l|}{ Surgical margin } \\
\hline Negative & 9733 & 92.3 & 6.7 & 1.0 & \multirow[t]{2}{*}{0.0011} \\
\hline Positive & 2536 & 90.0 & 8.6 & 1.3 & \\
\hline
\end{tabular}

Fig. 2). To further validate the prognostic power of MAPT, we tested within subsets of identical classical and quantitative Gleason score. In line with the Cox hazard ratio analysis (Additional file 1: Table S4), MAPT staining provided prognostic information beyond the Gleason score in subsets defined by an identical traditional Gleason score (Fig. 3a) and in the subgroup with $50-60 \%$ Gleason 4 pattern (Fig. 3g) defined by the quantitative Gleason score (Fig. 3b-h).

\section{Association with other key genomic deletions}

Previous studies showed that prostate cancers could be grouped by various somatic mutations including TMPRSS2:ERG fusions and PTEN, 3p13, 5q21 and 6q15 genomic deletions. These alterations are of interest because they are linked to poor prognosis and either to the ERG-fusion positive (PTEN, 3p) or the ERG-fusion negative subset $(5 q, 6 q)$. A comparison of MAPT expression levels with these deletions revealed a significant association between high MAPT expression and PTEN deletions irrespectively of the ERG status ( $p<0.0001$, Fig. 4$)$. MAPT expression was largely unrelated to other deletions. 
a) all

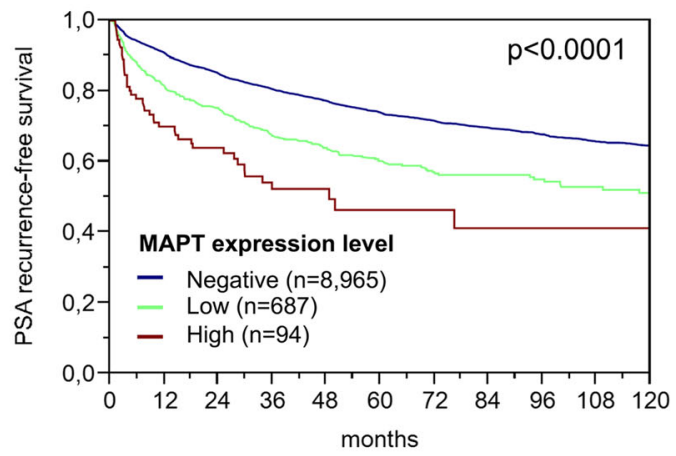

c) ERG-fusion positive cancers

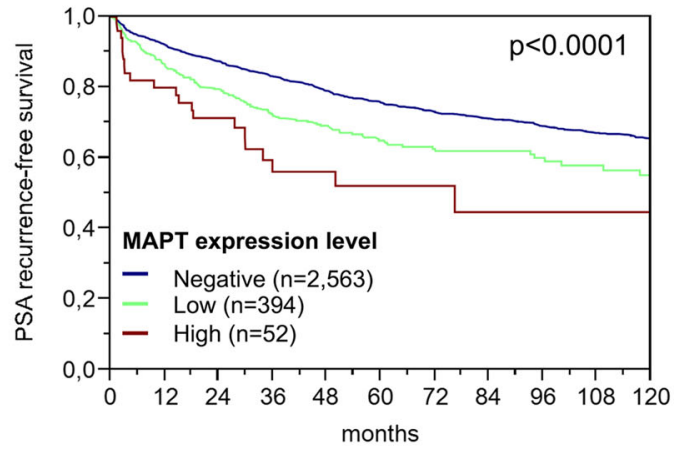

b) $E R G$-fusion negative

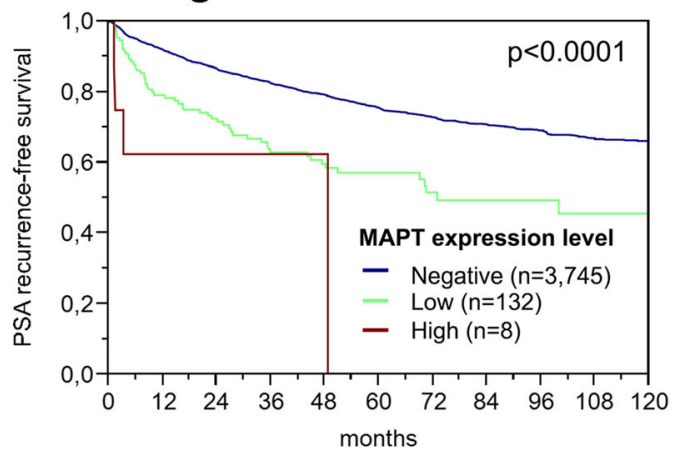

Fig. 2 Association between microtubule-associated protein Tau (MAPT) expression and prostate specific antigen (PSA) recurrence in (a) all cancers, (b) the TMPRSS2:ERG negative and (c) the TMPRSS2:ERG positive subset

\section{Multivariate analysis}

Four different scenarios were performed evaluating the clinical relevance of MAPT expression (Table 2). For example the preoperative scenario 4 included the Gleason grade obtained on the original biopsy, the PSA level, the CT stage and the MAPT expression. MAPT proved to be an independent prognostic parameter in all four scenarios when all tumors were analyzed ( $p<0.0001$ each, Table 2$)$. This held also true for ERG negative and ERG positive cancers $(p \leq 0.02$, Table 2$)$. The hazard ratios for PSA recurrence-free survival after prostatectomy for the univariate and multivariate model of the established preoperative prognostic parameters and MAPT expression (scenario 4) are shown in the Table S4. MAPT expression was an equally strong prognostic marker as the other known preoperative prognostic markers in both analyses.

\section{Discussion}

The results of our study identify MAPT overexpression as a moderate prognostic feature occurring in a relatively small subset of prostate cancers.

In this study, detectable MAPT expression was seen in about $8 \%$ of prostate cancers whereas normal prostate tissues remained negative under the selected experimental conditions. Only one study has analyzed MAPT expression by IHC in prostate cancer before. Cirak et al. reported $23 \%$ MAPT positive cases in a series of 30 prostate cancers [13]. It is well possible, that the large section approach of Cirak et al. lead to a higher detection rate of tumors with a heterogeneous MAPT expression. Our data indeed suggest that MAPT expression might be heterogeneous in a considerable fraction of tumors. Clear-cut heterogeneity was even found in some TMA spots (Fig. 1d) and a thorough analysis of all cancer-containing tissue blocks of three of our cancers with high MAPT expression on TMA spots always revealed both MAPT positive and MAPT negative cancer areas. Such heterogeneity represents a limitation for TMA studies analyzing only single spots per tumor.

MAPT overexpression was associated with to unfavorable tumor phenotype and early biochemical recurrence in this study $(p<0.0001$ each). The independent prognostic impact of MAPT overexpression from established prognostic parameters and the difference in the five-year recurrence rate of more than $20 \%$ between patients with and without detectable MAPT expression argues for a potential clinical relevance of this molecular feature. A similarly strong prognostic role has recently been described for aberrant $\beta$ III-tubulin (TUBB3) expression in prostate cancer. TUBB3 is a microtubule protein, which is normally expressed in cells of neuronal origin but 

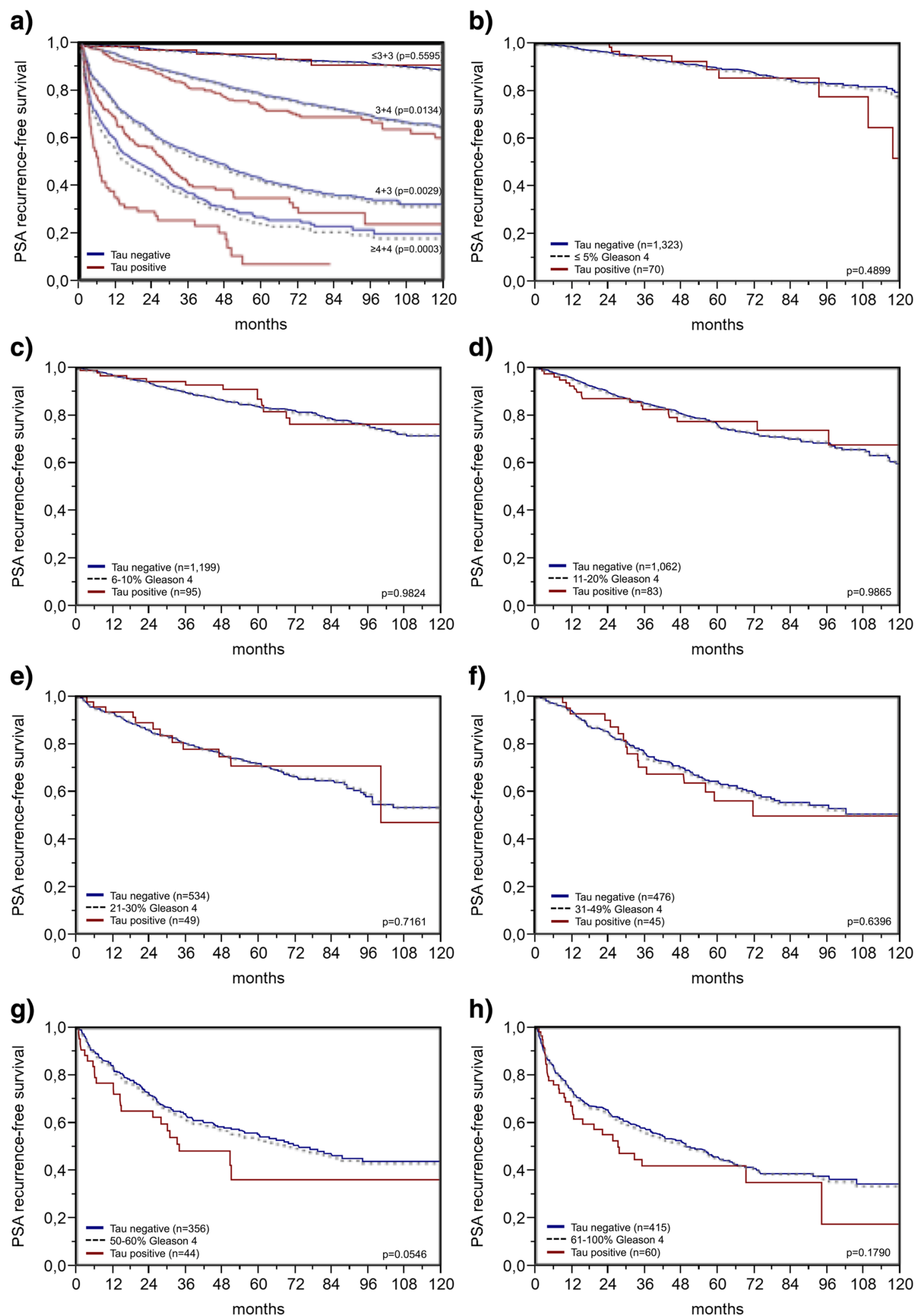

Fig. 3 Kaplan-Meier plots of prostate specific antigen (PSA) recurrence after radical prostatectomy and negative or positive (low and high) microtubule-associated protein Tau (MAPT) expression in subsets defined by (a) classical and (b-h) quantitative Gleason score, defined by the percentage of Gleason 4 grade 


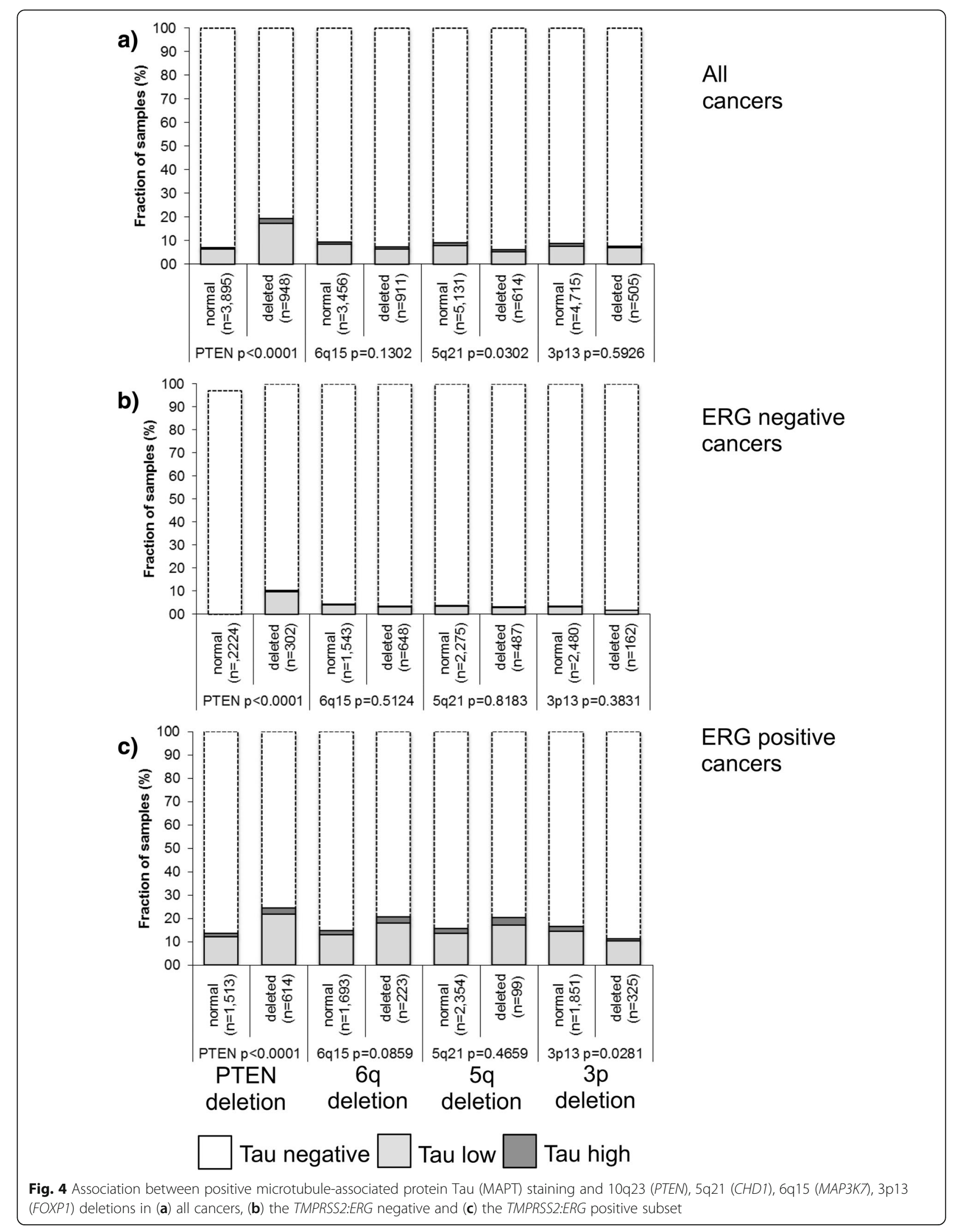


Table 2 Multivariate analyses including microtubule-associated protein Tau (MAPT) expression in all cancers, the ERG negative and ERG positive subset

\begin{tabular}{|c|c|c|c|c|c|c|c|c|c|c|}
\hline \multirow[b]{2}{*}{ Subset } & \multirow[b]{2}{*}{ Scenario $^{a}$} & \multirow[b]{2}{*}{ N } & \multicolumn{8}{|c|}{ P for PSA recurrence-free survival after prostatectomy } \\
\hline & & & $\begin{array}{l}\text { Preoperative } \\
\text { PSA-level }\end{array}$ & pT-stage & cT-stage & Gleason prostatectomy & Gleason biopsy & pN-stage & R-status & MAPT-expression \\
\hline \multicolumn{11}{|c|}{ All cancers } \\
\hline & 1 & 6467 & $<0.0001$ & $<0.0001$ & - & $<0.0001$ & - & $<0.0001$ & $<0.0001$ & $<0.0001$ \\
\hline & 2 & 9690 & $<0.0001$ & $<0.0001$ & - & $<0.0001$ & - & - & $<0.0001$ & $<0.0001$ \\
\hline & 3 & 9545 & $<0.0001$ & - & $<0.0001$ & $<0.0001$ & - & - & - & $<0.0001$ \\
\hline & 4 & 8146 & $<0.0001$ & - & $<0.0001$ & - & $<0.0001$ & - & - & $<0.0001$ \\
\hline \multicolumn{11}{|c|}{ ERG-negative } \\
\hline & 1 & 2541 & 0.0215 & $<0.0001$ & - & $<0.0001$ & - & 0.0005 & 0.0601 & 0.0195 \\
\hline & 2 & 3873 & 0.0013 & $<0.0001$ & - & $<0.0001$ & - & - & $<0.0001$ & 0.0180 \\
\hline & 3 & 3833 & $<0.0001$ & - & $<0.0001$ & $<0.0001$ & - & - & - & 0.0013 \\
\hline & 4 & 3779 & $<0.0001$ & - & $<0.0001$ & - & $<0.0001$ & - & - & $<0.0001$ \\
\hline \multicolumn{11}{|c|}{ ERG-positive } \\
\hline & 1 & 1900 & 0.0005 & $<0.0001$ & - & $<0.0001$ & - & 0.0145 & 0.0010 & 0.0122 \\
\hline & 2 & 2995 & $<0.0001$ & $<0.0001$ & - & $<0.0001$ & - & - & $<0.0001$ & 0.0185 \\
\hline & 3 & 2944 & $<0.0001$ & - & $<0.0001$ & $<0.0001$ & - & - & - & 0.0115 \\
\hline & 4 & 2900 & $<0.0001$ & - & $<0.0001$ & - & $<0.0001$ & - & - & 0.0003 \\
\hline
\end{tabular}

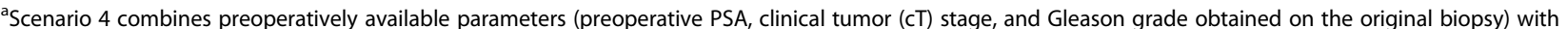
the postoperative MAPT expression. In scenario 3 the biopsy Gleason is replaced by the Gleason grade obtained on radical prostatectomy. In scenario 2 cT stage is superseeded by pathological tumor (pT) stage and surgical margin (R) status. In scenario 1 the lymph node (pN) stage is added

not in prostate epithelium [32]. Overall, the striking prognostic impact of the expression of proteins influencing structure and maintenance of microtubules suggest a considerable impact of composition and function of the cytoskeleton on the behavior of cancer cells.

The extensive molecular database attached to our TMA allowed us to further study the role of MAPT expression in prostate cancer and to search for possible interactions. About $50 \%$ of prostate cancers carry gene fusions linking the androgen-regulated TMPRSS2 with the transcription factor $E R G[26,33]$. As a result of this rearrangement, $E R G$ becomes androgen regulated and massively overexpressed. Our data demonstrate strikingly higher MAPT expression levels in ERG positive than in ERG negative cancers. This finding is consistent with data suggesting that ERG may have a regulatory role in microtubule dynamics $[17,34]$ and that ERG can even destabilize microtubules by binding soluble tubulin in the cytoplasm [35]. The exact molecular mechanism for this is unknown. According to the eukaryotic promoter database [36] MAPT is not a direct target of the $E R G$ transcription factor. It is possible, however, that ERG has an indirect impact on MAPT transcription through at least one of its more than 1600 target genes [37-39]. Our comparison of MAPT expression with frequent genomic deletions identified PTEN as the only deletion linked to high MAPT expression. This fits well to earlier work in neurodegenerative diseases reporting that PTEN can affect MAPT phosphorylation, aggregation or it's binding to microtubules [40, 41].

The existing data suggest a general role of MAPT protein in cancer. High rates of MAPT positivity have been reported from several other important cancer types including $43-52 \%$ in breast cancer [16, 42, 43], $63-74 \%$ in ovarian cancer [12, 44], and $55-70 \%$ in gastric cancer $[11,45,46]$. The clinical and prognostic value of MAPT may greatly depend on the tumor type. For example, high MAPT protein expression level has been linked to good prognosis in breast cancer [47], but to poor prognosis in ovarian cancer [12]. It is unknown why MAPT exerts a different impact on tumor cell aggressiveness in different cancer types. As the microtubule composition varies between cell types, it may be speculated that MAPT induced modifications of the microtubule dynamics may have a diverse impact on cell behavior depending on the tissue of origin. It is also known that MAPT interacts with other cancer related proteins and pathways. For example, it has been shown that MAPT can cooperate with various growth related kinases such PI3K, Fyn, cSrc, and Fgr $[14,48,49]$. Such kinases may have a different role in different cell types. Moreover, MAPT interactions depend on its phosphorylation status. Substantial differences in cell lines derived from prostate and brain cancers suggest that MAPT phosphorylation might strongly depend on the tumor type [14,50-52]. 
In several tumor types, MAPT has been suggested to represent a potential predictive marker in patients treated with taxanes [12, 46, 53-57]. MAPT competes with taxanes for the same binding site at the microtubules. Although MAPT stabilizes microtubules in the same way as paclitaxel, its binding is more reversible [18]. Consequently, overexpression of MAPT has been suggested to render microtubules insensitive to paclitaxel therapy $[18,58,59]$. In prostate cancer, taxanes are the most important cytotoxic agents for advanced metastatic disease. However, response rates in clinical studies (measured as a $50 \%$ decline of PSA) are about $45-50 \%$ [60]. It would be interesting to study the relationship between expression of proteins related to the microtubules system - such as MAPT and TUBB3 - and response to taxanes in prostate cancer in clinical trials.

\section{Conclusions}

MAPT expression is a moderate and independent prognostic factor in prostate cancer, which is particularly linked to PTEN-deleted cancers. Heterogeneity of expression within tumors may limit the practical use of MAPT measurement in clinical practice, however.

\section{Additional file}

Additional file 1: Table S1. Pathological and clinical data of the arrayed prostate cancers. Table S2. Association between microtubule-associated protein Tau (MAPT) staining results and prostate cancer phenotype in ERG fusion negative tumors. Table S3. Association between microtubuleassociated protein Tau (MAPT) staining results and prostate cancer phenotype in ERG fusion positive tumors. Table S4. Cox proportional hazards for PSA recurrence-free survival after prostatectomy of established preoperative prognostic parameter and MAPT expression. Figure S1. Association between positive microtubule-associated protein Tau (MAPT) staining and ERG status (IHC/FISH) in all cancers. (PDF $231 \mathrm{~kb})$

\section{Abbreviations}

CHD1: Chromodomain-Helicase-DNA-Binding Protein 1; FISH: Fluorescence in-situ hybridization; FOXP1: Forkhead box protein P1;

IHC: Immunohistochemistry; MAP3K7: Mitogen-Activated Protein Kinase Kinase Kinase 7; MAPT: Microtubule-associated protein Tau; PSA: Prostate specific antigen; PTEN: Phosphatase and tensin homolog; RPE: Radical prostatectomy; TMA: Tissue microarray; TMPRSS2:ERG: Transmembrane protease, serine 2: ETS-related gene fusion; TUBB3: Tubulin beta 3

\section{Acknowledgments}

We thank Julia Schumann, Sünje Seekamp and Inge Brandt for excellent technical assistance.

\section{Funding}

This work was supported by the Federal Ministry for Education and Research of Germany (BMBF) (grant no. 01KU1505B) to GS. The funding body had no involvement in the design of the study, collection, analysis, and interpretation of data and in writing the manuscript.

\section{Availability of data and materials}

All data generated or analyzed during this study are included in this published article [and its additional files].

\section{Author's contributions}

CS, JG, RS, SS and GS designed the study, and drafted the manuscript. HH, MG and TS participated in study design. CS, JG, DH and SM performed IHC analysis and scoring. FB, FJ, TC and EB participated in pathology data analysis. CH, CS and RS performed statistical analysis. TS, MK, and DL participated in data interpretation, and helped to draft the manuscript. All authors read and approved the final manuscript.

\section{Ethics approval and consent to participate}

The ethics committee of the Ärztekammer Hamburg approved this study (WF-049/09). According to local laws (HmbKHG, §12a) informed consent was not required for this study.

\section{Consent for publication}

Not applicable.

\section{Competing interests}

The authors declare that they have no competing interests.

\section{Publisher's Note}

Springer Nature remains neutral with regard to jurisdictional claims in published maps and institutional affiliations.

\section{Author details}

'Institute of Pathology, University Medical Center Hamburg-Eppendorf, Martinistrasse 52, D-20246 Hamburg, Germany. ${ }^{2}$ General, Visceral and Thoracic Surgery Department and Clinic, University Medical Center Hamburg-Eppendorf, Martinistrasse 52, D-20246 Hamburg, Germany. ${ }^{3}$ Martini-Clinic, Prostate Cancer Center, University Medical Center Hamburg-Eppendorf, Martinistrasse 52, D-20246 Hamburg, Germany. ${ }^{4}$ Department of Urology, Charité - Universitätsmedizin Berlin, Charitéplatz 1, D-10117 Berlin, Germany.

Received: 7 December 2018 Accepted: 20 February 2019

Published online: 01 March 2019

\section{References}

1. Torre LA, Bray F, Siegel RL, Ferlay J, Lortet-Tieulent J, Jemal A. Global cancer statistics, 2012. CA Cancer J Clin. 2015;65(2):87-108.

2. Wilt TJ, Brawer MK, Jones KM, Barry MJ, Aronson WJ, Fox S, Gingrich JR, Wei JT, Gilhooly P, Grob BM, et al. Radical prostatectomy versus observation for localized prostate cancer. N Engl J Med. 2012;367(3):203-13.

3. Thompson IM Jr, Tangen CM. Prostate cancer--uncertainty and a way forward. N Engl J Med. 2012;367(3):270-1.

4. Glaessgen A, Hamberg H, Pihl CG, Sundelin B, Nilsson B, Egevad L. Interobserver reproducibility of percent Gleason grade $4 / 5$ in total prostatectomy specimens. J Urol. 2002;168(5):2006-10.

5. Weingarten MD, Lockwood AH, Hwo SY, Kirschner MW. A protein factor essential for microtubule assembly. Proc Natl Acad Sci U S A. 1975;72(5): 1858-62.

6. Thurston VC, Zinkowski RP, Binder LI. Tau as a nucleolar protein in human nonneural cells in vitro and in vivo. Chromosoma. 1996;105(1):20-30.

7. Cross DC, Munoz JP, Hernandez P, Maccioni RB. Nuclear and cytoplasmic tau proteins from human nonneuronal cells share common structural and functional features with brain tau. J Cell Biochem. 2000;78(2):305-17.

8. Vanier MT, Neuville P, Michalik L, Launay JF. Expression of specific tau exons in normal and tumoral pancreatic acinar cells. J Cell Sci. 1998;111(Pt 10): 1419-32.

9. He W, Zhang D, Jiang J, Liu P, Wu C. The relationships between the chemosensitivity of human gastric cancer to paclitaxel and the expressions of class III beta-tubulin, MAPT, and survivin. Med Oncol. 2014;31(5):950.

10. Koo DH, Lee HJ, Ahn JH, Yoon DH, Kim SB, Gong G, Son BH, Ahn SH, Jung $\mathrm{KH}$. Tau and PTEN status as predictive markers for response to trastuzumab and paclitaxel in patients with HER2-positive breast cancer. Tumour Biol. 2015;36(8):5865-71.

11. Mimori K, Sadanaga N, Yoshikawa Y, Ishikawa K, Hashimoto M, Tanaka F, Sasaki A, Inoue H, Sugimachi K, Mori M. Reduced tau expression in gastric cancer can identify candidates for successful paclitaxel treatment. Br J Cancer. 2006;94(12):1894-7.

12. Smoter M, Bodnar L, Grala B, Stec R, Zieniuk K, Kozlowski W, Szczylik C. Tau protein as a potential predictive marker in epithelial ovarian cancer patients 
treated with paclitaxel/platinum first-line chemotherapy. J Exp Clin Cancer Res. 2013;32:25.

13. Cirak Y, Sarsik B, Cakar B, Sen S, Simsir A, Uslu R. Predictive and prognostic values of tau and BubR1 protein in prostate cancer and their relationship to the Gleason score. Med Oncol. 2013;30(2):526.

14. Souter S, Lee G. Microtubule-associated protein tau in human prostate cancer cells: isoforms, phosphorylation, and interactions. J Cell Biochem. 2009;108(3):555-64.

15. Sangrajrang S, Denoulet P, Millot G, Tatoud R, Podgorniak MP, Tew KD, Calvo F, Fellous A. Estramustine resistance correlates with tau over-expression in human prostatic carcinoma cells. Int J Cancer. 1998;77(4):626-31.

16. Pusztai L, Jeong JH, Gong Y, Ross JS, Kim C, Paik S, Rouzier R, Andre F, Hortobagyi GN, Wolmark N, et al. Evaluation of microtubule-associated protein-tau expression as a prognostic and predictive marker in the NSABPB 28 randomized clinical trial. J Clin Oncol. 2009;27(26):4287-92.

17. Birdsey GM, Dryden NH, Shah AV, Hannah R, Hall MD, Haskard DO, Parsons M, Mason JC, Zvelebil M, Gottgens B, et al. The transcription factor erg regulates expression of histone deacetylase 6 and multiple pathways involved in endothelial cell migration and angiogenesis. Blood. 2012;119(3):894-903.

18. Smoter M, Bodnar L, Duchnowska R, Stec R, Grala B, Szczylik C. The role of tau protein in resistance to paclitaxel. Cancer Chemother Pharmacol. 2011; 68(3):553-7.

19. Attard G, Parker C, Eeles RA, Schroder F, Tomlins SA, Tannock I, Drake CG, de Bono JS. Prostate cancer. Lancet. 2016;387(10013):70-82.

20. Tannock IF, Fizazi K, Ivanov S, Karlsson CT, Flechon A, Skoneczna I, Orlandi F, Gravis G, Matveev V, Bavbek S, et al. Aflibercept versus placebo in combination with docetaxel and prednisone for treatment of men with metastatic castration-resistant prostate cancer (VENICE): a phase 3, doubleblind randomised trial. Lancet Oncol. 2013;14(8):760-8.

21. Tannock IF, de Wit R, Berry WR, Horti J, Pluzanska A, Chi KN, Oudard S, Theodore C, James ND, Turesson I, et al. Docetaxel plus prednisone or mitoxantrone plus prednisone for advanced prostate cancer. N Engl J Med. 2004;351(15):1502-12.

22. Erbersdobler A, Hammerer P, Huland H, Henke RP. Numerical chromosomal aberrations in transition-zone carcinomas of the prostate. J Urol. 1997;158(4): 1594-8.

23. Sauter G, Steurer S, Clauditz TS, Krech T, Wittmer C, Lutz F, Lennartz M, Janssen T, Hakimi N, Simon R, et al. Clinical utility of quantitative Gleason grading in prostate biopsies and prostatectomy specimens. Eur Urol. 2016; 69(4):592-8.

24. Kononen J, Bubendorf L, Kallioniemi A, Barlund M, Schraml P, Leighton S, Torhorst J, Mihatsch MJ, Sauter G, Kallioniemi OP. Tissue microarrays for high-throughput molecular profiling of tumor specimens. Nat Med. 1998; 4(7):844-7.

25. Mirlacher M, Simon R. Recipient block TMA technique. Methods Mol Biol. 2010;664:37-44.

26. Weischenfeldt J, Simon R, Feuerbach L, Schlangen K, Weichenhan D, Minner S, Wuttig D, Warnatz HJ, Stehr H, Rausch T, et al. Integrative genomic analyses reveal an androgen-driven somatic alteration landscape in earlyonset prostate cancer. Cancer Cell. 2013;23(2):159-70.

27. Minner S, Enodien M, Sirma H, Luebke AM, Krohn A, Mayer PS, Simon R, Tennstedt P, Muller J, Scholz L, et al. ERG status is unrelated to PSA recurrence in radically operated prostate cancer in the absence of antihormonal therapy. Clin Cancer Res. 2011;17(18):5878-88.

28. Burkhardt L, Fuchs S, Krohn A, Masser S, Mader M, Kluth M, Bachmann F, Huland H, Steuber T, Graefen M, et al. CHD1 is a 5q21 tumor suppressor required for ERG rearrangement in prostate cancer. Cancer Res. 2013;73(9): 2795-805.

29. Kluth M, Hesse J, Heinl A, Krohn A, Steurer S, Sirma H, Simon R, Mayer PS, Schumacher U, Grupp K, et al. Genomic deletion of MAP3K7 at 6q12-22 is associated with early PSA recurrence in prostate cancer and absence of TMPRSS2:ERG fusions. Mod Pathol. 2013;26(7):975-83.

30. Krohn A, Diedler T, Burkhardt L, Mayer PS, De Silva C, Meyer-Kornblum M, Kotschau D, Tennstedt P, Huang J, Gerhauser C, et al. Genomic deletion of PTEN is associated with tumor progression and early PSA recurrence in ERG fusion-positive and fusion-negative prostate Cancer. Am J Pathol. 2012; 181(2):401-12.

31. Krohn A, Seidel A, Burkhardt L, Bachmann F, Mader M, Grupp K, Eichenauer T, Becker A, Adam M, Graefen M, et al. Recurrent deletion of 3p13 targets multiple tumor suppressor genes and defines a distinct subgroup of aggressive ERG fusion positive prostate cancers. J Pathol. 2013;231(1):130-41.
32. Tsourlakis MC, Weigand P, Grupp K, Kluth M, Steurer S, Schlomm T, Graefen M, Huland $\mathrm{H}$, Salomon G, Steuber T, et al. betalll-tubulin overexpression is an independent predictor of prostate cancer progression tightly linked to ERG fusion status and PTEN deletion. Am J Pathol. 2014;184(3):609-17.

33. Tomlins SA, Rhodes DR, Perner S, Dhanasekaran SM, Mehra R, Sun XW, Varambally S, Cao X, Tchinda J, Kuefer R, et al. Recurrent fusion of TMPRSS2 and ETS transcription factor genes in prostate cancer. Science. 2005;310(5748):644-8.

34. Chow A, Amemiya Y, Sugar L, Nam R, Seth A. Whole-transcriptome analysis reveals established and novel associations with TMPRSS2:ERG fusion in prostate cancer. Anticancer Res. 2012;32(9):3629-41.

35. Galletti G, Matov A, Beltran H, Fontugne J, Miguel Mosquera J, Cheung C, MacDonald TY, Sung M, O'Toole S, Kench JG, et al. ERG induces taxane resistance in castration-resistant prostate cancer. Nat Commun. 2014;5:5548.

36. Perier RC, Praz V, Junier T, Bonnard C, Bucher P. The eukaryotic promoter database (EPD). Nucleic Acids Res. 2000;28(1):302-3.

37. Bawa P, Zackaria S, Verma M, Gupta S, Srivatsan R, Chaudhary B, Srinivasan S. Integrative analysis of Normal long intergenic non-coding RNAs in prostate Cancer. PLoS One. 2015;10(5):e0122143.

38. Brase JC, Johannes M, Mannsperger H, Falth M, Metzger J, Kacprzyk LA, Andrasiuk T, Gade S, Meister M, Sirma H, et al. TMPRSS2-ERG -specific transcriptional modulation is associated with prostate cancer biomarkers and TGF-beta signaling. BMC Cancer. 2011;11:507.

39. Taylor BS, Schultz N, Hieronymus H, Gopalan A, Xiao Y, Carver BS, Arora VK, Kaushik P, Cerami E, Reva B, et al. Integrative genomic profiling of human prostate cancer. Cancer Cell. 2010;18(1):11-22.

40. Zhang X, Li F, Bulloj A, Zhang YW, Tong G, Zhang Z, Liao FF, Xu H. Tumorsuppressor PTEN affects tau phosphorylation, aggregation, and binding to microtubules. FASEB J. 2006;20(8):1272-4.

41. Kerr F, Rickle A, Nayeem N, Brandner S, Cowburn RF, Lovestone S. PTEN, a negative regulator of $\mathrm{PI} 3$ kinase signalling, alters tau phosphorylation in cells by mechanisms independent of GSK-3. FEBS Lett. 2006;580(13):3121-8.

42. Li ZH, Xiong QY, Tu JH, Gong Y, Qiu W, Zhang HQ, Wei WS, Hou YF, Cui WQ. Tau proteins expressions in advanced breast cancer and its significance in taxane-containing neoadjuvant chemotherapy. Med Oncol. 2013;30(3):591.

43. Shao YY, Kuo KT, Hu FC, Lu YS, Huang CS, Liau JY, Lee WC, Hsu C, Kuo WH, Chang KJ, et al. Predictive and prognostic values of tau and ERCC1 in advanced breast cancer patients treated with paclitaxel and cisplatin. Jpn J Clin Oncol. 2010;40(4):286-93.

44. Steffensen KD, Smoter M, Waldstrom M, Grala B, Bodnar L, Stec R, Szczylik C, Jakobsen A. Resistance to first line platinum paclitaxel chemotherapy in serous epithelial ovarian cancer: the prediction value of ERCC1 and tau expression. Int J Oncol. 2014;44(5):1736-44.

45. Wang Q, Wang N, Shao G, Qian J, Shen D, Fei Y, Mao W, Wu D. Relationship between gastric cancer tau protein expression and paclitaxel sensitivity. Pathol Oncol Res. 2013;19(3):429-35.

46. Yu J, Gao J, Lu Z, Gong J, Li Y, Dong B, Li Z, Zhang X, Shen L. Combination of microtubule associated protein-tau and beta-tubulin III predicts chemosensitivity of paclitaxel in patients with advanced gastric cancer. Eur J Cancer. 2014;50(13):2328-35.

47. Bonneau C, Gurard-Levin ZA, Andre F, Pusztai L, Rouzier R. Predictive and prognostic value of the TauProtein in breast Cancer. Anticancer Res. 2015; 35(10):5179-84.

48. Lee G, Newman ST, Gard DL, Band H, Panchamoorthy G. Tau interacts with src-family non-receptor tyrosine kinases. J Cell Sci. 1998;111(Pt 21):3167-77.

49. Reynolds CH, Garwood CJ, Wray S, Price C, Kellie S, Perera T, Zvelebil M, Yang A, Sheppard PW, Varndell IM, et al. Phosphorylation regulates tau interactions with Src homology 3 domains of phosphatidylinositol 3-kinase, phospholipase Cgamma1, Grb2, and Src family kinases. J Biol Chem. 2008; 283(26):18177-86

50. Brandt R, Lee G, Teplow DB, Shalloway D, Abdel-Ghany M. Differential effect of phosphorylation and substrate modulation on tau's ability to promote microtubule growth and nucleation. J Biol Chem. 1994;269(16):11776-82.

51. Utton MA, Vandecandelaere A, Wagner U, Reynolds CH, Gibb GM, Miller CC, Bayley PM, Anderton BH. Phosphorylation of tau by glycogen synthase kinase 3 beta affects the ability of tau to promote microtubule self-assembly. Biochem J. 1997:323(Pt 3):741-7.

52. Drewes G, Trinczek B, Illenberger S, Biernat J, Schmitt-Ulms G, Meyer HE, Mandelkow EM, Mandelkow E. Microtubule-associated protein/microtubule affinity-regulating kinase (p110mark). A novel protein kinase that regulates tau-microtubule interactions and dynamic instability by phosphorylation at the Alzheimer-specific site serine 262. J Biol Chem. 1995;270(13):7679-88. 
53. Rouzier R, Rajan R, Wagner P, Hess KR, Gold DL, Stec J, Ayers M, Ross JS, Zhang P, Buchholz TA, et al. Microtubule-associated protein tau: a marker of paclitaxel sensitivity in breast cancer. Proc Natl Acad Sci U S A. 2005;102(23): 8315-20.

54. Wu H, Huang M, Lu M, Zhu W, Shu Y, Cao P, Liu P. Regulation of microtubule-associated protein tau (MAPT) by miR-34c-5p determines the chemosensitivity of gastric cancer to paclitaxel. Cancer Chemother Pharmacol. 2013;71(5):1159-71.

55. Zhou J, Qian S, Li H, He W, Tan X, Zhang Q, Han G, Chen G, Luo R. Predictive value of microtubule-associated protein tau in patients with recurrent and metastatic breast cancer treated with taxane-containing palliative chemotherapy. Tumour Biol. 2015;36(5):3941-7.

56. Wang K, Deng QT, Liao N, Zhang GC, Liu YH, Xu FP, Zu J, Li XR, Wu YL. Tau expression correlated with breast cancer sensitivity to taxanes-based neoadjuvant chemotherapy. Tumour Biol. 2013;34(1):33-8.

57. Wosnitzer MS, Domingo-Domenech J, Castillo-Martin M, Ritch C, Mansukhani M, Petrylack DP, Benson MC, McKiernan JM, Cordon-Cardo C. Predictive value of microtubule associated proteins tau and stathmin in patients with nonmuscle invasive bladder cancer receiving adjuvant intravesical taxane therapy. J Urol. 2011;186(5):2094-100.

58. Ikeda H, Taira N, Hara F, Fujita T, Yamamoto H, Soh J, Toyooka S, Nogami T, Shien T, Doihara $\mathrm{H}$, et al. The estrogen receptor influences microtubuleassociated protein tau (MAPT) expression and the selective estrogen receptor inhibitor fulvestrant downregulates MAPT and increases the sensitivity to taxane in breast cancer cells. Breast Cancer Res. 2010;12(3):R43.

59. Wagner P, Wang B, Clark E, Lee H, Rouzier R, Pusztai L. Microtubule associated protein (MAP)-tau: a novel mediator of paclitaxel sensitivity in vitro and in vivo. Cell Cycle. 2005;4(9):1149-52.

60. Hwang C. Overcoming docetaxel resistance in prostate cancer: a perspective review. Ther Adv Med Oncol. 2012;4(6):329-40.

\section{Ready to submit your research? Choose BMC and benefit from:}

- fast, convenient online submission

- thorough peer review by experienced researchers in your field

- rapid publication on acceptance

- support for research data, including large and complex data types

- gold Open Access which fosters wider collaboration and increased citations

- maximum visibility for your research: over $100 \mathrm{M}$ website views per year

At $\mathrm{BMC}$, research is always in progress.

Learn more biomedcentral.com/submissions 